\title{
PENENTUAN KESESUAIAN LAHAN KONSERVASI HUTAN MANGROVE DI DESA GOTOWASI KECAMATAN MABA SELATAN MALUKU UTARA
}

\author{
Sri Endah Widiyanti ${ }^{\mathrm{a} *}$, Salim Abubakar ${ }^{\mathrm{a}}$, dan Mufti Abd. Murhum ${ }^{\mathrm{b}}$ \\ ${ }^{a}$ Manajemen Sumberdaya Perairan, FPIK, Universitas Khairun, Ternate, Indonesia \\ ${ }^{\mathrm{b}}$ Budidaya Perairan, FPIK, Universitas Khairun, Ternate, Indonesia \\ *Corresponding author: endah_unkhair@yahoo.com
}

\begin{abstract}
Abstrak
Desa Gotowasi merupakan salah satu desa yang berada dalam wilayah Kecamatan Maba Selatan Kabupaten Halmahera Timur, Maluku Utara. Desa ini termasuk desa pesisir yang memiliki tiga ekosistem pesisir yakni ekosistem hutan mangrove, padang lamun dan terumbu karang. Ketiga ekosistem ini terancam tercemar akibat sumber polusi potensial melalui aktivitas pertambangan nikel di sekitarnya. Penelitian ini bertujuan untuk mengetahui komposisi jenis mangrove dan menganalisis kesesuaian lahan konservasi mangrove di wilayah pesisir Desa Gotowasi Kecamatan Maba Selatan dengan menggunakan parameter kesesuaian lahan berdasarkan parameter kondisi biofisik. Hasil penelitian menunjukkan bahwa hutan mangrove di Desa Gotowasi memiliki keanekaragaman jenis lebih tinggi dari semua wilayah di Kabupaten Halmahera Timur. Penyebaran hutan mangrove tersebar diseluruh wilayah desa dengan komposisi jenis sebanyak 9 famili dan 18 jenis mangrove. Pemetaan daerah konservasi dilakukan dengan menggunakan aplikasi pengindaraan jarak jauh dan system informasi geografis, selanjutnya dilanjutkan dengan indeks kesesuaian kawasan konservasi. Hasil analisis menunjukan kawasan hutan mangrove masuk dalam kategori sangat sesuai (S1). Dengan demikian, kontrol dan konservasi adalah langkah yang tepat yang harus segera dilakukan untuk melindungi ekosistem hutan mangrove yang ada di pesisir Desa Gotowasi.
\end{abstract}

Kata Kunci: Kesesuaian lahan, konservasi, mangrove

\begin{abstract}
Gotowasi Village is one of villages in Maba Subdistrict area, Regency of Eastern Halmahera. This village is included in coastal village which had a lot of potential fishery resources as well as potential coastal ecosystem like mangrove forest, seagrass and coral reef ecosystems. However this village also had opportunity and potential pollution source by nickel mining that can damage resources, especially ecosystem of mangrove forest. This research purposed to analyze conservation area suitability of mangrove in Gotowasi Village coastal area, Southern Maba Subdistrict using suitability parameters based on biophysic condition. Research result showed that mangrove forest of Gotowasi Village had the highest biodiversity of all area in Eastern Halmahera Regency. Mangrove forest distribution in this village was almost all of their area, from near village's shoreline until Cape of Leisippo, there were 9 families and 18 species of mangroves. The mapping of conservation area was conducted by remote sensing and geographic information system, furthermore determining of suitability index of conservation area. Analysis result showed that mangrove forest area was included in the most suitability (S1). Thereby, control and conservation were appropriate action for protecting mangrove forest ecosystem in Gotowasi Village.
\end{abstract}

Keywords: conservation, mangrove, suitability area

\section{PENDAHULUAN}

Hutan mangrove merupakan sumberdaya alam yang memiliki beberapa sifat kekhususan, diantaranya karena letaknya yang sangat spesifik, peran ekologisnya yang khas, dan potensi yang bernilai ekonomis tinggi. Hutan mangrove termasuk sumberdaya alam yang dapat dipulihkan pendayagunaanya sehingga memerlukan penanganan yang tepat, terutama untuk mencegah musnahnya sumberdaya alam tersebut dan menjamin kelestarian di masa kini dan masa yang akan datang [1]. Ekosistem hutan mangrove adalah suatu ekosistem peralihan antara darat dan laut. Ekosistem ini terdapat di daerah tropik atau sub tropik, berada di sepanjang pantai yang terlindung serta muara sungai. Selain itu, 
ekosistem hutan mangrove merupakan komunitas tumbuhan pantai yang didominasi oleh beberapa jenis pohon mangrove. Tumbuhan ini mampu tumbuh dan berkembang pada daerah pasang surut sesuai, dengan toleransinya terhadap salinitas, lama penggenangan, substrat dan morfologi pantainya [2].

Sejalan dengan pertumbuhan penduduk dan pesatnya kegiatan pembangunan di berbagai bidang, baik fisik maupun ekonomi, secara langsung maupun tidak langsung telah mempengaruhi keadaan hutan mangrove di Indonesia. Hutan mangrove semakin terdesak dan semakin berkurang luasnya sehingga dikuatirkan akan terjadi penurunan fungsi hutan mangrove yang sangat penting baik dari segi pembangunan ekonomi maupun dari segi kelestarian lingkungan. Salah satu faktor yang berperan penting dalam menentukan kehidupan dan kelestarian ekosistem mangrove adalah aktivitas manusia, misalnya konversi lahan mangrove menjadi lahan pertanian, perikanan dan pemukiman. Dampak potensial yang muncul dapat mengancam regenerasi stok ikan maupun udang di perairan lepas pantai yang memerlukan hutan mangrove dan terjadinya pencemaran laut oleh bahan pencemar. Oleh karena itu diperlukan upaya-upaya pengelolaan lingkungan hidup yang dapat menjamin keberlanjutan ekosistem hutan mangrove [3].

Desa Gotowasi merupakan salah satu desa yang berada dalam wilayah Kecamatan Maba Selatan Kabupaten Halmahera Timur, Maluku Utara. Desa ini termasuk desa pesisir yang memiliki tiga ekosistem pesisir yakni ekosistem hutan mangrove, padang lamun dan terumbu karang. Hutan mangrove desa ini termasuk dalam kawasan hutan mangrove terbesar di Kabupaten Timur, selain hutan mangrove di Desa Tewil, Desa Waci dan Desa Bicoli. Luas hutan mangrove Desa Gotowasi berdasarkan hasil pemetaan dengan menggunakan aplikasi pengindaran jarak jauh dan sistem geografis (Citra Landsat 8) yaitu 432,43 Ha. Selain itu, hutan mangrove ini berada dalam kawasan pertambangan nikel, yang dikuatirkan akan tercemar oleh sumber polusi potensial dari aktivitas pertambangan nikel di sekitarnya. Pada akhirnya, fungsi ekosistem hutan mangrove sebagai pendukung ekosistem padang lamun, ekosistem terumbu karang dan habitat organisme yang berasosiasi akan terganggu.

Salah satu upaya untuk mengatasi permasalahan di atas adalah konservasi. Upaya konservasi dapat digunakan sebagai alat untuk melindungi ekosistem hutan mangrove di kawasan tersebut. Upaya konservasi ini telah mendapat dukungan dari pemerintah daerah setempat melalui Rencana Zonasi Wilayah Pesisir dan Pulau-Pulau Kecil (RZWP3K) Kabupaten Halmahera Timur Tahun 2012-2022. Langkah awal yang dapat dilakukan adalah melakukan analisis kesesuaian lahan hutan mangrove Desa Gotowasi untuk kawasan konservasi.

Tujuan penelitian ini adalah untuk mengetahui komposisi jenis mangrove (1), dan menganalisis kesesuaian lahan konservasi mangrove di wilayah pesisir Desa Gotowasi Kecamatan Maba Selatan dengan menggunakan parameter kesesuaian lahan berdasarkan parameter kondisi biofisik (2). Hasil analisis ini diharapkan dapat digunakan sebagai bahan pertimbangan untuk melestarikan atau melindungi hutan mangrove dan ekologinya, melalui pengurangan dampak sosial ekonomi maupun pengembangan kegiatan lainnya, seperti perusahaan nikel yang dapat mengancam berkelanjutan ekosistem hutan mangrove tersebut. Untuk itu diperlukan data dan informasi yang bersifat keruangan (peta) untuk mendukung upaya pengelolaan kawasan konservasi di pesisir Desa Gotowasi.

\section{MATERI DAN METODE PENELITIAN}

Penelitian ini telah dilakukan mulai bulan Januari sampai Maret 2017 di hutan mangrove Desa Gotowasi Kecamatan Maba Selatan Kabupaten Halmahera Utara Propinsi Maluku Utara. Lokasi penelitian secara geografis dapat dilihat pada Gambar 1.

\section{Pengambilan Data}

Pengambilan data dalam penelitian ini diawali dengan penentuan stasiun dan pengumpulan data yang dilanjutkan dengan 
analisis biofisik. Data yang dikumpulkan dalam penelitian ini merupakan data yang berkaitan dengan indikator kesesuaian lahan untuk konservasi hutan mangrove.

Beberapa stasiun penelitian dipertimbangkan melalui observasi awal di lapangan. Kemudian ditetapkan 6 stasiun yang dianggap mewakili lokasi tersebut. Keenam stasiun penelitian $\left(S_{t}\right)$ tersebut adalah $S_{t} 1$ Woyo Pakal, $\mathrm{S}_{\mathrm{t}} 2$ Gesei, $\mathrm{S}_{\mathrm{t}} 3$ Leisippo, $\mathrm{S}_{\mathrm{t}} 4$ Sibenindi, $\mathrm{S}_{\mathrm{t}} 5$ Woli dan $\mathrm{S}_{\mathrm{t}} 6$ Kukuwou.

Pengambilan data untuk indikator Kesesuaian Lahan meliputi vegetasi mangrove, organisme, substrat dasar, kemiringan lereng, pasang surut, $\mathrm{pH}$ tanah dan kecepatan arus. Pangambilan contoh vegetasi mangrove dilakukan dengan menggunakan metode "spot chek" [4]. Ketebalan mangrove setiap stasiun diukur secara manual menggunakan roll meter yang ditarik secara vertikal mulai dari zona depan sampai zona belakang. Transek ditarik tegak lurus dari garis pantai di sepanjang vegetasi mangrove. Pada setiap transek, data vegetasi dicuplik dengan menggunakan plot berukuran $10 \mathrm{mx}$ $10 \mathrm{~m}$ untuk kategori pohon (diamater $>4 \mathrm{~cm}$ ), $5 \mathrm{~m}$ x $5 \mathrm{~m}$ untuk kategori anakan (diameter $<4$ $\mathrm{cm}$ tinggi $>1 \mathrm{~m}$ ) dan $2 \mathrm{~m} \times 2 \mathrm{~m}$ untuk kategori semaian (tinggi $<1 \mathrm{~m}$ ). Ada 3 lintasan di setiap stasiun, dan masing-masing lintasan ditempatkan 5 buah plot. Untuk identifikasi vegetasi mangrove, diambil contoh biologis berupa komponen daun, bunga dan buah, serta diukur lingkaran batang pohon setinggi dada. Identifikasi vegetasi mangrove mengacu pada buku panduan pengenalan mangrove di Indonesia [5].

Organisme yang dikumpulkan terdiri dari ikan dan organisme akuatik yang berasosiasi di hutan mangrove. Ikan dikumpulkan dengan jaring insang (gill net, mesh size 2 inch). Jaring insang dipasang di zona depan hutan mangrove pada saat air menjelang surut, dengan asumsi bahwa ikan akan keluar dari hutan mangrove untuk mencari areal yang lebih dalam sehingga dapat terjerat pada jaring. Kemudian ikan hasil tangkapan dideterminasi berdasarkan petunjuk [6]. Pengambilan biota akuatik di ekosistem hutan mangrove menggunakan metode transek kuadrat. Pengambilan contoh biota akuatik mengikuti transek mangrove $(10 \mathrm{~m} \times 10 \mathrm{~m})$ yang ditarik tegak lurus dari garis pantai menuju daratan di sepanjang vegetasi mangrove, dan dalam setiap transek mangrove dibuat 5 sub transek (1 m x $1 \mathrm{~m})$. Selanjutnya, contoh biota akuatik yang diperoleh diidentifikasi menggunakan buku identifikasi [7]-[9].

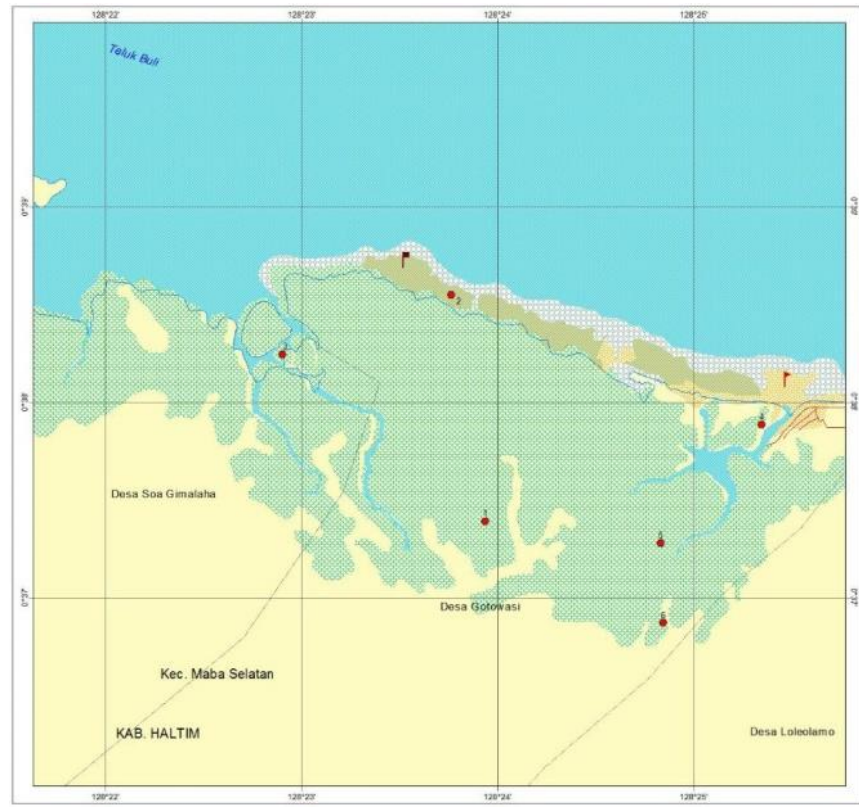

Gambar 1. Peta Lokasi Penelitian

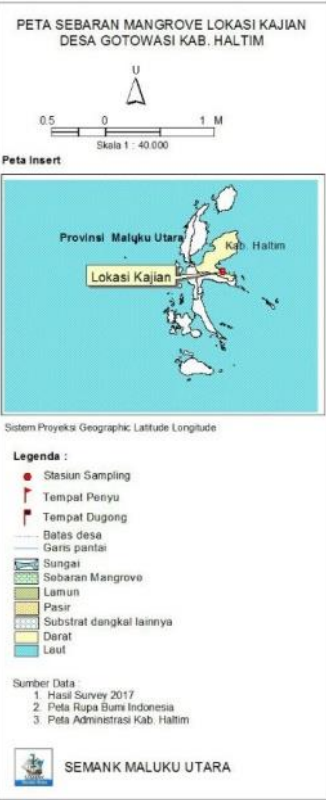

SEMANK MALUKU UTARA 
Contoh substrat dasar diambil dengan pipa paralon (PVC, diameter 2,5 inch) yang ditancapkan ke permukaan substrat hingga kedalaman $20 \mathrm{~cm}$. Pengambilan contoh substrat dasar ini dilakukan di 3 titik yang berbeda, kemudian dicampur menjadi satu dan dimasukkan ke dalam kantong plastik yang telah diberi label sesuai dengan jenis mangrove (metode komposit). Untuk keperluan analisis tekstur substrat, dibutuhkan $500 \mathrm{~g}$ contoh substrat [10]. Analisis ini dilakukan di Laboratorium Fisika dan Konservasi Tanah dan Laboratorium Kimia dan Kesuburan Tanah Fakultas Pertanian Universitas Samratulangi Manado.

Kemiringan lereng lahan hutan mangrove diukur pada saat surut terendah pada setiap profil dengan menggunakan "Profiler" yang dirakit berupa dua tonggak papan yang dihubungkan dengan tali sepanjang $50 \mathrm{~cm}$ dan diberi tali busur derajat pada salah satu tonggak [10].

Data pasang surut diperoleh melalui prosedur pemasangan rambu pasut yang ditempatkan pada lokasi penelitian, dimana pada saat pasang tertinggi dan surut terendah masih terendam air. Pengukuran pasang surut dilakukan selama 39 jam dengan interval waktu 1 jam [11].

Pengambilan data $\mathrm{pH}$ tanah menggunakan Soil Tester dengan cara mencelupkan ujung bawah alat ke dalam substrat dan kemudian amati angka $\mathrm{pH}$ pada display.

Kecepatan arus diukur dengan menggunakan tali sepanjang 2 meter dan bola pimpong, tali direntang searah dengan arah arus kemudian bola pimpong dilepaskan sampai ke ujung tali dan dihitung waktu bola pimpong sampai ke ujung tali tersebut dengan menggunakan stopwatch [12].

\section{Analisa Data}

Kerapatan jenis $\left(D_{i}\right)$, yaitu jumlah individu jenis i dalam suatu area yang diukur [13]:

Keterangan :

$$
D_{i}=n i /_{A}
$$

$\mathrm{D}_{\mathrm{i}}=$ kerapatan jenis- $\mathrm{i}$

$\mathrm{n}_{\mathrm{i}}=$ jumlah total individu dari jenis- $\mathrm{i}$

$\mathrm{A}=$ luas areal total pengambilan contoh

Tabel 1. Matriks Kesesuaian Lahan Konservasi Hutan Mangrove [16, 17, 18]

\begin{tabular}{|c|c|c|c|c|c|c|c|}
\hline \multirow[b]{2}{*}{ No. } & \multirow[b]{2}{*}{ Parameter } & \multirow[b]{2}{*}{ Bobot } & \multicolumn{4}{|c|}{ Kelas* } & \multirow[b]{2}{*}{ Ket. } \\
\hline & & & S1 & S2 & S3 & $\mathrm{N}$ & \\
\hline 1 & Ketebalan Mangrove (m) & 20 & $>500$ & $>200-500$ & $50-200$ & $<50$ & \\
\hline 2 & $\begin{array}{l}\text { Kerapatan } \quad \text { Mangrove } \\
\left(100 \mathrm{~m}^{2}\right)\end{array}$ & 20 & $>15-25$ & $>10-15$ & $5-10$ & $<5$ & Nilai Skor \\
\hline 3 & Jenis Mangrove & 10 & $>5$ & $\begin{array}{c}3-5 \\
\text { Alami }\end{array}$ & $1-2$ & 0 & Kelas : \\
\hline 4 & Kealamiahan & 10 & Alami & $\begin{array}{l}\text { dengan } \\
\text { tambahan }\end{array}$ & $\begin{array}{l}\text { Lahan } \\
\text { rehabiltasi }\end{array}$ & Buatan & $\mathrm{S} 1=3$ \\
\hline 5 & jenis biota) & 10 & $\begin{array}{c}>4 \\
\text { Lumpur }\end{array}$ & $\begin{array}{c}3-4 \\
\text { Pasir }\end{array}$ & 2 & biota & $\mathrm{S} 2=2$ \\
\hline 6 & Substrat Dasar & 5 & berpasir & berlumpur & Pasir & Berbatu & $\mathrm{S} 3=1$ \\
\hline 7 & Kemiringan & 5 & $<10$ & $10-25$ & $>25-45$ & $>45$ & $\mathrm{~N}=0$ \\
\hline 8 & Jarak dari Sungai & 5 & $<0,5$ & $>0,5-1$ & $>1-2$ & $>2$ & \\
\hline 9 & Pasang Surut (m) & 5 & $0-1$ & $\begin{array}{c}>1-2 \\
5-<6 \text { dan }\end{array}$ & $\begin{array}{c}>2-5 \\
4-<5 \text { dan }\end{array}$ & $>5$ & $\begin{array}{l}\text { Nilai maks } \\
\quad=300\end{array}$ \\
\hline 10 & $\mathrm{pH}$ & 5 & $6-7$ & $>7-8$ & $>8-9$ & $<4$ dan $>9$ & \\
\hline 11 & Kecepatan arus (m/dt) & 5 & $<0,3$ & $0,3-0,4$ & $0,41-0,5$ & $>0,5$ & \\
\hline
\end{tabular}


Prinsip dasar analisis Kesesuaian Lahan Konservasi Mangrove [14] adalah hasil dari perkalian skor dan bobot yang diperoleh dari setiap parameter. Kesesuaian lahan untuk kawasan konservasi ditentukan dari nilai indeks kesesuaian kawasan (IKK, \%). Nilai IKK adalah penjumlahan dari nilai seluruh parameter. Parameter-parameter yang ditetapkan adalah parameter biofisika yang dianggap sebagai indikator untuk menentukan kesesuaian atau tingkat kecocokan bagi sebuah kawasan konservasi hutan mangrove (Tabel 1). Tingkat kesesuaian lahan untuk kawasan konservasi hutan mangrove terdiri dari 3 kelas, yaitu Sangat Sesuai (S1), Sesuai (S2), Sesuai Bersyarat (S3) dan Tidak Sesuai (N). Persamaan IKK ini diadaptasi dari rumus untuk menentukan tingkat kesesuaian lahan wisata menurut [15]:

$$
I K K=\sum\left[\frac{N i}{\text { Nmaks }}\right] \times 100 \%
$$

Keterangan :

IKK = Indeks kesesuaian kawasan

$\mathrm{Ni}=$ Nilai parameter ke-I (Bobot $\mathrm{x}$ Skor)

Nmaks = Nilai maksimum dari suatu

\section{HASIL DAN PEMBAHASAN}

Kesesuaian lahan merupakan salah satu komponen yang penting dalam menentukan kawasan konservasi mangrove di suatu wilayah. Untuk itu fokus kajian kesesuaian lahan pada studi ini adalah pengamatan ekosistem mangrove yang berkaitan dengan struktur komunitas vegetasi mangrove dan karakteristik lingkungannya [18].

Berdasarkan hasil pemetaan dengan menggunakan aplikasi pengindaran jarak jauh dan sistem geografis (Citra Landsat 8) diperoleh luas total hutan mangrove di Desa Gotowasi sebesar 432,43 Ha dengan kategori kerapatan padat sebesar 81,27 Ha, kerapatan sedang 244,80 Ha dan kerapatan jarang 106,38 Ha (Gambar 2).

Jumlah jenis mangrove yang ditemukan di keenam stasiun penelitian adalah 18 jenis, yang berasal dari 9 famili. Stasiun Woyo Pakal memiliki 10 jenis mangrove, yaitu
Bruguiera gymnorrizha, B. parviflora, Ceriops tagal, C. decandra, Rhizophora apiculata, $R$. Stylosa, $R$. mucronata, Xylocarpus granatum, X. Moluccensis dan Sonneratia alba. Ketebalan hutan mangrove di stasiun ini adalah $320 \mathrm{~m}$ dengan rata-rata kerapatan $45 \mathrm{~m}^{2}$. Hal yang sama juga untuk stasiun Gesei, jenis mangrove di stasiun ini 10 jenis, yaitu B. gymnorrizha, B. parviflora, B. sexangula, Avicennia alba, $C$. tagal, $R$. apiculata, $R$. Stylosa, $R$. mucronata, $X$. granatum dan $X$. Moluccensis. Ketebatalan hutan mangrove di stasiun Gesei $402 \mathrm{~m}$ dengan rata-rata kerapatan $39 \mathrm{~m}^{2}$. Hutan mangrove pada Stasiun Woyo Pakal dan Gesei masih dalam kondisi baik karena masih alami dan tidak ada pemanfaatan dari masyarakat.

Komposisi jenis mangrove pada Stasiun Leisippo sebanyak 8 jenis yaitu $B$. gymnorrizha, B. parviflora, $C$. tagal, $C$. decandra, $R$. apiculata, $R$. Stylosa, $R$. mucronata dan $S$. alba. Ketebalan hutan mangrove rata-rata 370 meter dengan kerapatan $34 \mathrm{~m}^{2}$. Kondisi sebagian hutan mangrove sudah rusak karena dimanfaatkan oleh masyarakat sebagai tempat penjemuran ikan teri. Komposisi jenis mangrove pada Stasiun Sibenendi juga sebanyak 8 jenis, yaitu $B$. gymnorrizha, $C$. decandra, $R$. apiculata, Lumnitzera littorea, X. granatum, S. alba, Heritiera littoralis dan Acrostichum speciosum. Ketebatalan hutan mangrove di stasiun ini rata-rata $60 \mathrm{~m}$ dengan kerapatan 21 $\mathrm{m}^{2}$. Kondisinya termasuk dalam kategori rusak sedang karena lahannya dikonversi menjadi jalan raya dan sebagian masyarakat memanfaatkan sebagai kayu bakar. Hutan mangrove di stasiun ini sangat dekat dengan pemukiman sehingga peluang pemanfaatan sangatlah tinggi. Ini dapat dilihat dari banyaknya lahan mangrove yang telah rusak, namun Dinas Kehutanan Kabupaten Halmahera Timur telah melakukan upaya pemulihan berupa kegiatan rehabilitasi dengan tingkat keberhasilan $75 \%$.

Komposisi jenis mangrove tertinggi dari semua stasiun pengamatan terdapat pada Stasiun Woli dengan jumlah 14 jenis yaitu $B$. gymnorrizha, B. parviflora, B. sexangula, $C$. decandra, $R$. apiculata, $R$. Stylosa, $R$. 
mucronata, L. littorea, L. racemosa, S. alba, Excoecaria agallocha, $H$. littoralis, $X$. granatum dan $X$. moluccensis. Ketebatalan hutan mangrove di stasiun ini rata-rata $425 \mathrm{~m}$ dengan kerapatan $67 \mathrm{~m}^{2}$. Komposisi jenis mangrove pada Stasiun Kukuwou sebanyak 7 jenis yaitu B. gymnorrizha, B. parviflora, $R$. apiculata, $R$. mucronata, Nypa fruticans, $X$. granatum dan $X$. moluccensis. Kondisi hutan mangrove sebagian sudah rusak karena sebagian lahan hutan dimanfaatkan masyarakat sebagai jembatan dan jalan perahu. Ketebatalan hutan mangrove di stasiun ini rata-rata $415 \mathrm{~m}$ dengan kerapatan $27 \mathrm{~m}^{2}$.

Berdasarkan hasil studi di enam stasiun pengamatan hutan mangrove (Stasiun Tanjung Tapalo, Gesei, Leisippo, Sibenindi Woli dan Kukuwou), diperoleh 13 famili dan 18 jenis ikan dari Ordo Perciformes. yaitu 9 jenis ikan dari hutan mangrove. Jumlah biota akuatik lain yang berasosiasi di ekosistem ini adalah 34 jenis yang berasal dari 23 famili. Biota tersebut terdiri dari 2 jenis Echinodermata, 7 jenis Bivalvia, 15 jenis Gastropoda, 9 jenis Crustacea dan 2 jenis reptil. Jenis biota dari Kelas Gastropoda lebih mendominasi dibandingkan biota dari kelas atau filum yang lainnya, dan selanjutnya diikuti oleh Kelas Bivalvia. Keanekaragaman jenis biota ini menunjukkan bahwa ekosistem hutan mangrove di Desa Gotowasi mendukung keberadaan biota ( $>30$ jenis). Rata-rata biota yang diperoleh setiap stasiun sebanyak 13 jenis sehingga semua stasiun berada dalam kategori sangat sesuai untuk kawasan konservasi hutan mangrove. Menurut [14], kawasan hutan mangrove yang memiliki jumlah biota lebih dari 4 jenis dapat dijadikan sebagai kawasan konservasi.

Lahan yang sesuai untuk ekosistem mangrove adalah lahan yang ditujukan sebagai kawasan mangrove dimana lahan ini memiliki potensi yang lebih besar dalam perkembangan mangrove dibandingkan lahan yang ditujukan untuk kawasan lain [19].

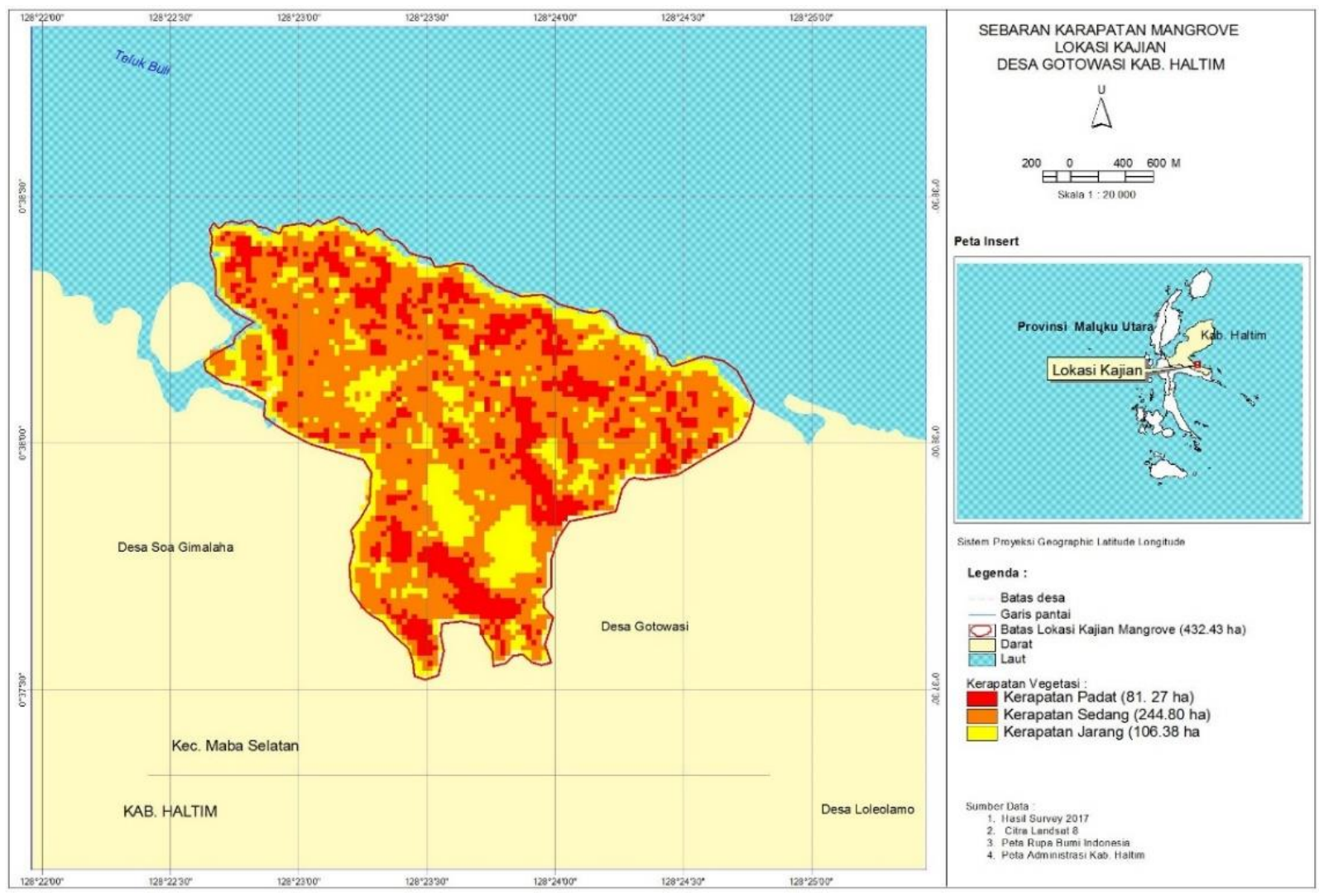

Gambar 2. Sebaran Kerapatan Mangrove Desa Gotowasi 
Jenis substrat yang diperoleh terdiri dari dua jenis yaitu lempung berpasir dan pasir berlempung. Substrat lempung berpasir terdapat di lima (5) stasiun penelitian, yaitu $\mathrm{S}_{\mathrm{t}} 1$ Woyo Pakal, $\mathrm{S}_{\mathrm{t}} 2$ Gesei, $\mathrm{S}_{\mathrm{t}} 4$ Sibenindi, $\mathrm{S}_{\mathrm{t}} 5$ Woli dan $\mathrm{S}_{\mathrm{t}} 6$ Kukuwou, sedangkan jenis substrat pasir berlempung hanya terdapat pada $\mathrm{S}_{\mathrm{t}} 3$ Leisippo. Hasil analisis ini sesuai dengan hasil penelitian $[10,20]$ pada lahan mangrove yang masih alami, umumnya jenis tekstur tanah lahan mangrove yang masih alami adalah lempung berpasir. Dari hasil analisis tersebut, paramater substrat dikategorikan sangat sesuai untuk dijadikan kawasan konservasi mangrove. Menurut [2], substrat lumpur sesuai untuk beberapa spesies mangrove seperti Avicennia marina, Rhizophora mucronata dan Sonneratia alba. Perbedaan jenis substrat akan mempengaruhi jenis mangrove yang akan hidup di suatu daerah. Selain itu, hasil analisis jenis substrat juga dapat dimanfaatkan untuk pemilihan jenis mangrove yang akan ditanam dalam suatu kegiatan rehabilitasi [21].

Hasil pengukuran $\mathrm{pH}$ tanah untuk semua stasiun memiliki kisaran $\mathrm{pH}$ bersifat asam $(6,3$ - 6,5). Menurut [14], hutan mengrove yang memiliki kisaran $\mathrm{pH}$ tanah 6-7 sangat sesuai untuk dijadikan kawasan konservasi hutan mangrove. Dari kisaran nilai $\mathrm{pH}$ ini, maka semua stasiun penelitian sangat sesuai untuk dijadikan sebagai kawasan konservasi. $\mathrm{pH}$ tanah yag terdapat pada ekositem hutan mangrove umumnya bersifat asam. Hal ini disebabkan oleh akumulasi timbunan bahan organik yang berasal penambahan residu berupa daun, ranting, cabang dan akar yang jatuh kepermukaan sedimen, serta perombakan tersebut oleh jasad mikro. Ini sesuai dengan pernyataan [10] bahwa $\mathrm{pH}$ tanah pada ekositem hutan mangrove dipengaruhi oleh penimbunan bahan organik dalam sedimen berupa daun, ranting, cabang dan akar yang jatuh ke permukaan sedimen serta adanya proses dekomposisi oleh mkroorganisme.

Kemiringan lereng pada setiap stasiun penelitian berturut-turut adalah $2,10 \%$ pada $\mathrm{S}_{\mathrm{t}} 1$ Woyo; Pakal adalah, 2,29\% pada $\mathrm{S}_{\mathrm{t}} 2$ (Gesei); 1,56\% pada $\mathrm{S}_{\mathrm{t}} 3$ Leisippo, 1,47\% pada $\mathrm{S}_{\mathrm{t}} 4$ Sibenendi; $1,62 \%$ pada $\mathrm{S} 55$ (Woli) dan
$2,67 \%$ pada $\mathrm{S}_{\mathrm{t}} 6$ Kukuwou. Secara keseluruhan, nilai kemiringan lereng pada semua stasiun termasuk dalam kriteria lereng datar $(0-8 \%)$. Bagian lahan yang terdapat mangrove umumnya berlereng datar $(0-8 \%)$ sedangkan pada bagian lahan yang tidak terdapat mangrove berlereng landai $(8-15 \%)$ [10]. Lebih lanjut dikatakan [18] bahwa kemiringan lereng yang sangat sesuai untuk kawasan konservasi hutan mangrove yaitu < $10 \%$.

Berdasarkan hasil analisis pasang surut oleh Dinas Hidro-Oseanografi TNI AL, pasang surut di kawasan hutan mangrove Desa Gotowasi termasuk dalam tipe campuran dominasi ganda (Mixed semi diurnal, $\mathrm{F}=$ $0,50)$, dengan tinggi pasang surut rata-rata 122 $\mathrm{cm}$. Tipe ini ditandai dengan terjadinya dua kali pasang dan dua kali surut dalam sehari yang tingginya hampir sama [22]. Dari hasil yang diperoleh tersebut $(F=0,5)$, dapat dikatakan bahwa lokasi penelitian termasuk dalam kategori baik untuk kawasan konservasi hutan mangrove. Ini sesuai dengan pernyataan [14], bahwa kawasan konservasi hutan mangrove yang baik memiliki kisaran pasang surut antara 0-1. Pada zona pasang surut ini terdapat jenis api-api (Avicennia spp.), Prapat (Sonneratia alba) dan di tepi sungai umumnya didominasi oleh Rhizophora mucronata [5]. Selain itu, pasang surut menentukan zonasi komunitas flora dan fauna mangrove. Durasi pasang surut berpengaruh besar terhadap perubahan salinitas pada areal mangrove. Pada areal yang selalu tergenang hanya Rhizophora mucronata yang tumbuh baik, sedangkan Bruguiera spp dan Xylocarpus spp jarang mendominasi daerah yang sering tergenang. Pasang surut juga berpengaruh terhadap perpindahan massa antara air tawar dengan air laut, dan oleh karena itu mempengaruhi organisme mangrove yang berasosiasi [23].

Hasil pengukuran kecepatan arus berkisar antara $0,048-0,054 \mathrm{~m} / \mathrm{dtk}$. Ini menunjukkan arus di semua stasiun tergolong arus lambat. Ini sesuai dengan pengelompokan kecepatan arus [24], bahwa kecepatan arus dapat dikelompokkan menjadi arus sangat cepat $(>1 \mathrm{~m} / \mathrm{dt})$, arus cepat $(0,5-1$ $\mathrm{m} / \mathrm{dt})$, arus sedang $(0,1-0,5 \mathrm{~m} / \mathrm{dt})$ dan arus 
Tabel 2. Hasil analisis kesesuaian lahan konservasi hutan mangrove

\begin{tabular}{|c|c|c|c|c|c|c|c|}
\hline \multirow[b]{2}{*}{ No. } & \multirow[b]{2}{*}{ Parameter } & \multicolumn{6}{|c|}{ Stasiun Penelitian } \\
\hline & & $\begin{array}{l}\text { Woyo } \\
\text { Pakal }\end{array}$ & Gesei & Leisippo & Sibenendi & Woli & Kukuwou \\
\hline 1 & Ketebalan Mangrove (m) & 40 & 40 & 40 & 20 & 40 & 40 \\
\hline 2 & Kerapatan Mangrove $\left(100 \mathrm{~m}^{2}\right)$ & 60 & 60 & 60 & 60 & 60 & 60 \\
\hline 3 & Jenis Mangrove & 30 & 30 & 30 & 30 & 30 & 30 \\
\hline 4 & Kealamiahan & 30 & 30 & 30 & 20 & 30 & 30 \\
\hline 5 & Obyek Biota (Jumlah jenis biota) & 30 & 30 & 30 & 30 & 30 & 30 \\
\hline 6 & Substrat Dasar & 15 & 15 & 10 & 15 & 15 & 15 \\
\hline 7 & Kemiringan & 15 & 15 & 15 & 15 & 15 & 15 \\
\hline 8 & Jarak dari Sungai & 5 & 10 & 5 & 15 & 15 & 15 \\
\hline 9 & Pasang Surut (m) & 15 & 15 & 15 & 15 & 15 & 15 \\
\hline 10 & $\mathrm{pH}$ & 15 & 15 & 15 & 15 & 15 & 15 \\
\hline 11 & Kecepatan arus (m/dt) & 15 & 15 & 15 & 15 & 15 & 15 \\
\hline & Total & 270 & 275 & 265 & 250 & 280 & 280 \\
\hline & Kesimpulan & $\begin{array}{l}\text { Sangat } \\
\text { sesuai }\end{array}$ & $\begin{array}{l}\text { Sangat } \\
\text { sesuai }\end{array}$ & $\begin{array}{c}\text { Sangat } \\
\text { sesuai }\end{array}$ & $\begin{array}{l}\text { Sangat } \\
\text { sesuai }\end{array}$ & $\begin{array}{l}\text { Sangat } \\
\text { sesuai }\end{array}$ & $\begin{array}{l}\text { Sangat } \\
\text { sesuai }\end{array}$ \\
\hline
\end{tabular}

lanibat $(<0,1 \mathrm{~m} / \mathrm{dt})$ Lebih lanjut [14] menyatakan bahwa kawasan yang memiliki kecapatan arus < 0,3 adalah kawasan yang sangat sesuai untuk kawasan konservasi mangrove. Selain itu, mangrove akan hidup optimal pada daerah yang terlindung dari arus yang kuat, seperti wilayah pesisir yang memiliki muara sungai besar dan delta yang aliran airnya banyak mengandung lumpur. Sebaliknya, mangrove sulit tumbuh di wilayah pesisir yang terjal dan berombak besar dengan arus pasang surut yang kuat, karena kondisi ini tidak memungkinkan terjadinya pengendapan lumpur yang diperlukan sebagai substrat bagi pertumbuhannya [23].

Hasil analisis kesesuaian lahan untuk kawasan konservasi mangrove di Desa Gotowasi Kecamatan Maba Selatan menunjukkan bahwa semua stasiun penelitian berada pada kelas S1 atau sangat sesuai (Tabel 2).

Tabel 2 memperlihatkan kisaran nilai skor untuk konservasi mangrove sebesar 250 - 280. Pada Stasiun Woli dan Kukuwou memiliki total nilai skor sebesar 280, selanjutnya diikuti oleh Stasiun Gesei (275), Stasiun Woyo Pakal (270), Stasiun Leisippo (265) dan Stasiun Sibenindi (250). Dengan demikian dapat disimpulkan bahwa semua stasiun penelitian berada dalam kategori sangat sangat sesuai dijadikan kawasan konservasi hutan mangrove berdasarkan pernyataan [12] bahwa kisaran nilai IKK sebesar 226-300\% dikategorikan sangat sesuai (S1).

Ekosistem mangrove merupakan daerah ekoton yang menghubungkan antara ekosistem pesisir dengan daratan yang bersifat dinamis, memiliki fungsi dan peran penting untuk penunjang sistem penyangga kehidupan [19].

Oleh karena itu, hutan mangrove di Desa Gotowasi harus segera dikelola sesuai dengan fungsi dan peruntukkan lahannya melalui upaya rehabilitasi atau konservasi. Khususnya kawasan hutan mangrove yang telah mengalami penurunan kualitas lingkungan atau kerusakan. Selain itu, diperlukan komitmen dalam memanfaatkan sumberdaya hutan mangrove secara berkelanjutan, salah satunya melalui kegiatan restorasi dan pengelolaan hutan mangrove.

Penelitian-penelitian yang dilakukan dewasa tidak hanya mengkaji mengenai ekologi, struktur dan fungsi ekosistem mangrove saja, tetapi perlu penetapan kerangka kerja pengelolaan ekosistem mangrove sebagai acuan pengelolaan. Oleh karena itu, diperlukan koordinasi dan inisiasi dengan desa maupun pemerintah daerah 
setempat untuk menetapkan ekosistem hutan mangrove Desa Gotowasi sebagai Kawasan Konservasi Laut Daerah (KKLD), sehingga sumberdaya ekosistem hutan mangrove dapat dikelola secara berkelanjutan dan memberikan manfaat secara berkelanjutan pula bagi masyarakat desa.

\section{KESIMPULAN}

Kesimpulan yang diperoleh hasil dari penelitian ini yaitu :

1. Komposisi jenis mangrove di Desa Gotowasi Kecamatan Maba Selatan sebanyak 18 jenis yaitu Rhizopora apiculata, $R$. mucronata, $R$. stylosa, Bruguiera gymnorrhiza, B. parviflora, $B$. sexangula, Ceriops decandra, C. tagal, Sonneratia alba, Xylocarpus granatum, $X$. moluccensis, Avicennia alba, Heritiera littoralis, Lumnitzera littorea, $L$. racemosa, Sonneratia alba, Excoecaria agallocha, Nypa fruticans dan Acrostichum speciosum.

2. Semua stasiun penelitian (Woyo Pakal, Gesei, Leisippo, Sibenindi, Woli dan Kukuwou) sangat sesuai (S1) dijadikan sebagai kawasan konservasi hutan mangrove di Desa Gotowasi Kecamatan Maba Selatan.

\section{UCAPAN TERIMAKASIH}

Penulis mengucapkan terima kasih kepada Yayasan SEMANK Maluku Utara dan Yayasan Burung Indonesia yang telah mendanai penelitian ini. Selain itu, terima kasih pada masyarakat Desa Gotowasi yang telah mendukung kegiatan pengambilan data dengan menyediakan fasilitas dan diskusinya selama berada di lapangan.

\section{DAFTAR PUSTAKA}

[1] Z. Alwidakdo, L. Azham, Kamarubayana, "Studi pertumbuhan mangrove pada kegiatan rehabilitasi mangrove di Desa Tanjung Limau Kecamatan Muara Badak Kabupaten Kutai Kartanegara," Jurnal AGRIFOR, vol. XIII no. 1, Maret 2014. ISSN : 14126885 .

[2] Suryono, "Sukses usaha pembibitan mangrove sang penyelamat laut," Penerbit Pustaka Baru Press. Yogyakarta, 2013.

[3] D. Muksin, S. Abubakar, "Pemanfaatan ekosistem hutan mangrove di Kecamatan Jailolo Kabupaten Halmahera Barat Provinsi Maluku Utara," Jurnal Ilmiah Prospek, vol. XIII, edisi 1 Januari 2011.

[4] S. Abubakar, "Hubungan kerapatan mangrove dengan kepadatan organisme akuatik di Pulau Donrotu Kecamatan Jailolo Selatan Kabupaten Halmahera Barat," Jurnal Vegetasi Biologi, vol. 2, no. 2 September 2012.

[5] Y. R. Noor, M. Khazali, dan N.N. Suryadiputra, "Panduan pengenalan mangrove di Indonesia," Ditjen PHKA dan Wetlands International Indonesia Programme, Bogor, 2005.

[6] T. Peristiwady, "Ikan-ikan laut ekonomis penting di Indonesia - petunjuk identifikasi," Penerbit LIPI. Jakarta, 2006.

[7] Dharma, " Recent and fossil Indonesian shell," Conch Book. PT. Ikrar Mandiri abadi. Jakarta, 2005.

[8] J. Romimohtarto dan S. Juwana, "Biologi laut - ilmu pengetahuan tentang biota," Penerbit Djambatan. Jakarta, 2001.

[9] G. Allen, "Panduan dasar untuk pengenalan ikan karang," Terangi Indonesia, (Terjemahan), 2004.

[10] S. Abubakar, Rina, "Analisis kesesuaian lahan rehabilitasi berdasarkan tinjauan tipologi pantai di Desa Guraping Kecamatan Oba Utara Kota Tidore Kepulauan," Hasil Penelitian, Lembaga Penelitian dan Pengabdian Pada 
Masyarakat Universitas Khairun. Ternate, 2016.

[11] Hasriyanti, "Tipe gelombang dan pasang surut di Perairan Pulau Dutungan Kabupaten Barru Sulawesi Selatan," Jurnal Sainsmat, Maret 2015.

[12] E. Magdalena, A. Sutrisno, dan P. Frida, "Analisis kesesuaian lahan bagi konservasi mangrove di Desa Timbul Sloko Kecamatan Sayung, Demak," Diponegoro Journal of Maquares, vol. 4, no. 3, 2015.

[13] G. Bengen, "Pedoman teknis pengenalan dan pengelolaan ekosistem mangrove," Pusat Kajian Sumberdaya Pesisir dan Lautan, Institut Pertanian Bogor, 2003.

[14] M. K. Wardhani, "Analisis kesesuaian lahan konservasi hutan mangrove di pesisir Selatan Kabupaten Bangkalan," Jurnal Kelautan, vol. 7, no. 2, Okt 2014.

[15] F. Yulianda, "Ekowisata bahari sebagai alternatif pemanfaatan sumberdaya pesisir berbasis konservasi," Disampaikan pada Seminar Sains 21 Peb 2007, Departemen MSP, Fakultas Perikanan dan Ilmu Kelautan, IPB, Bogor.

[16] M. K. Wardhani, “Analisis keberlanjutan kawasan potensi wisata pantai di pesisir selatan Kabupaten Bangkalan," Tesis, Sekolah Pascasarjana Institut Pertanian Bogor, 2011.

[17] A. A. F. Hutabarat, A. Yulianda, S. Fahrudin dan K. Harteti, " Pengelolaan pesisir dan laut secara terpadu," Pusdiklat Kehutanan Departemen Kehutanan RI. SECEM-Korea International Coorporation Agency. Bogor, 2009.
[18] Khomsin, "Studi perencanaan konservasi kawasan mangrove di pesisir selatan Kabupaten Sampang dengan teknologi penginderaan jauh dan sistem informasi geografis," Pertemuan Ilmiah Tahunan MAPIN XIV. Pemanfaatan Efektif Penginderaan Jauh Untuk Peningkatan Kesejahteraan Bangsa, Institut Teknologi Sepuluh November Surabaya, $14-15$ Sept 2005.

[19] A. Kustanti, "Manajemen hutan mangrove,” PT. IPB Press. Bogor, 2011.

[20] H. Stanly, "Kajian sedimen lahan mangrove bekas tambak yang telah direhabilitasi secara fisik di sebelah Timur Desa Tiwoho Kecamatan Wori," Skripsi, Fakultas Perikanan dan Ilmu Kelautan UNSRAT, Manado, 2005.

[21] Direktorat Pesisir dan Lautan, "Pedoman pengelolaan ekosistem mangrove," Departemen Kelautan dan Perikanan Direktorat Jenderal Kelautan, Pesisir dan Pulau - Pulau Kecil. Jakarta, 2005.

[22] O. S. R. Ongkosan, dan Suyarso, "Pasang surut," Lembaga Ilmu Pengetahuan Indonesia, Pusat Penelitian dan Pengembangan Oseanologi, Jakarta, 257 hal, 1989.

[23] A. Saru, "Mengungkap potensi emas hijau di wilayah pesisir," Penerbit Masagena Press. Makassar, 2013.

[24] Y. Reinnamah, "Pengaruh faktor oceanografi terhadap pertumbuhan mangrove (Rhizophora apiculata) dengan menggunakan metode buis bamboo di Pantai Oesapa Kecamatan Kelapa Lika Kota Kupang," 